\title{
波による堤体前面の洗掘，海岸侵食に対する 人工海草の防止効果
}

\section{1. まえがき}

防波堤や突堤などの構造物は，波や流孔によって基礎 周辺の海底が洗掘され, 沈下や耐波安定性の低下を生ず る. そのために, これら堤体の基礎にはグラベルマット やアスファルトマット等の洗掘防止工法が行孔れ，その 改良工法も種々提案されているけれども, 周辺洗掘を解 決する有力な工法とはなっていないようで西り, 現在で も新工法開発の要請が高い, 一方, 海岸侵食は, わが国 沿岸の多くの場所で発生して䄧り, 砂浜が後退茄るいは 消失し，ひいては国土保全上賀威なものとなっている。

著者らは，影観を阻害しないことを前提条件としたう 光で，底質移動の制御を図ることを目的に，波や流れの 中で柔軟に動摇する“人工海草”に取り組み，これまで に水理模型実験によってその基本的な機能について検討 してきた。ここれよれば, 進行波のもとでは人工海草は その植生区域内に底質を堆積させる効果とその岸側に底 質を移送させる効果がある（菅原・入江，1990）。

本研究法, 人工海草がさらに具体的な堤体前面の重複 波領域に缷汓る海底洗掘, 海岸侵食の対策工法となる可 能性を検討するために二つの移動床模型実験を行い，有 用と考学ら礼る結果を得たので報告するものである。

\section{2. 堤体前面の海底洗掘に対する人工海草模型 実験}

\section{（1）堤体前面の地形変化の概要}

重複波領域汇括汀る海底洗掘については, 多くの研究 が行われ，最近ではその機構が泳ぼ明らかになってい る.すなわら重複波のもとでは腹・節を境にして, 水粒 子運動が対称的であり，これによって生ずる底質移動に よる地形は, 波の腹節に依存して対称的な変化を示す. 地形変化は，波の諸元と底質の特性によって腹で洗掘し て節で堆積する場合之, 逆に腹で堆積して節で洗掘され る場合がある。入江ら（1984）は，これらの発生機構を 含めて発生限界を明らかにしている。これによれば底質 の移動方向は, 主として進行波の底面に和汀る水粒子最

* 正会員 運輸省港湾技術研究所海洋水理部主任研究官

** 正会員運輸省港涉技術研究所海洋水理部海象調査研究窒長
菅原一晃*. 永并紀彦**

大速度 $u_{b}$ と底質の沈降速度 $\omega$ との比 $u_{b} / \omega$ により支 配され，ub/ $\omega>10$ の場合以重複波の節の位置で洗掘さ れて腹の位置で堆積し， $u_{b} / \omega<10$ の場合は腹と節の中 間で洗掘されて節の位置で堆積する，前者をL一タイプ 洗掘, 後者をNータイプ洗掘と呼えでいる.ここで, 現

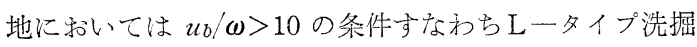
が発生しているものと推定される。

\section{(2) 実験施設と実験概要}

本実験で用い沉二次元造波水路を図一1儿示す，水路 以長さ $25 \mathrm{~m}$, 幅 $1 \mathrm{~m}$, 深岂 $0.65 \mathrm{~m}$ の鋼製で, 片面ガ ラス張り，床面は木製である。亦路は岸側端から $14 \mathrm{~m}$ の間が鋼製隔壁で二等分さ礼ている，造波装置はフラッ プ型で，周期 $0.2 \sim 2.5 \mathrm{~s}$ ，最大波高 $20 \mathrm{~cm}$ の規則波を 発生できる.

堤体の模型は高さ $62 \mathrm{~cm}$, 幅約 $50 \mathrm{~cm}$, 厚さ $18 \mathrm{~mm}$ のベニア板で，ガラス侧壁を有寸る水路側飞鉛直に立て て固定した、移動床は堤体前面から沖侧 $400 \mathrm{~cm}$ の間を 厚さ $10 \mathrm{~cm}$ に水平汇敷き均し, その沛側 端性 $1: 3$ の

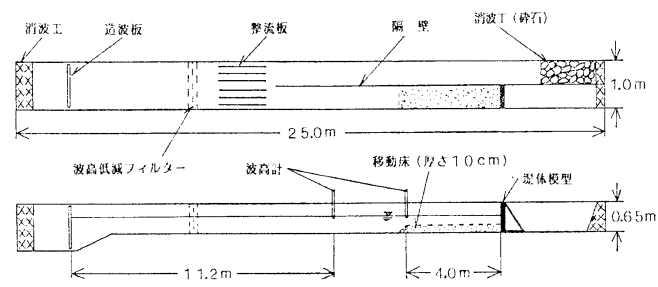

図-1 堤体前面の洗㻕対策実験の概要

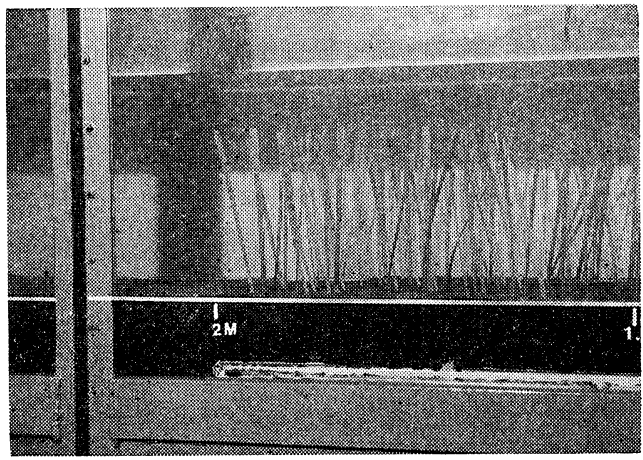

写真-1人工海草の設置状沉（後出ヶース $\mathrm{A}-2$ ) 
勾配で水路床面にすりつけた初期地形としてある. 底質 は中央粒径 $d_{50}=0.17 \mathrm{~mm}$ であり, その比重は 2.75 で ある・

人工海草は岸沖長さ $100 \mathrm{~cm}$, 幅約 $50 \mathrm{~cm}$, 厚さ $5 \mathrm{~mm}$ のベニア製基盤に葉状体の一端を固定して立ち上げ，林 立するよらに多数取り付けたもので, その設置例を写 真一1 に示す. 葉状体は波の方向に面を向けて千鳥状に 配列した。葉状体の植生間隔は岸沖, 横断方向とも $5 \mathrm{~cm}$ で計 180 株植生してあり, その植生密度は 0.036 株 $/ \mathrm{cm}^{2}$, である．基盤は水路床面に固定し，その上に底質を敷き 均してある. ここで, 葉状体とは人工海草を構成する最 小単位の 1 本（本実験では1 本が1株）を呼んでいる.

\section{（3）実験条件および実験方法}

実験波心，進行波（堤体，人工海草および移動床のな い状態）の沖側測点で $H=10 \mathrm{~cm} ， T=1.6 \mathrm{~s}$ となるもの で（1）で述べたように，節で洗掘されるLータイプ 洗掘の条件 $u b / \omega>10$ を満足する $u_{b} / \omega=12.3$ である. 水深は沖側固定床部で $40 \mathrm{~cm}$, 初期地形面で $30 \mathrm{~cm}$ で ある.波の作用時間は，人工海草なしのヶースにおいて 地形がほぼ安定したと判断された延べ 6 時間である.こ こでの測定項目は，地形および波高である.

波高の測定には容量式を使用し，造波板から $11.2 \mathrm{~m}$ の沖側測点と堤体から $400 \mathrm{~cm}$ の位置で測定するととも に，重複波の波形を把握するために波作用 $2 \sim 4$ 時間の 間に，堤体から $300 \mathrm{~cm}$ までを $5 \mathrm{~cm}$ 間隔に測定した。 湘定は水路縦断万向の中央に打ける 1 測線とし，30波の 連続波形をペン書きオシログラフによって取得した.

地形の測定は，水路縦断方向にガラス側壁より $10 \mathrm{~cm}$, $25 \mathrm{~cm}, 40 \mathrm{~cm}$ の 3 測線に执いて, 原則之して初期地形, $1,2,4,6$ 時間後にポイントゲージによって行っ た. 地形の岸沖測定間隔は $5 \mathrm{~cm}$ である.

表一1 に実験ケースを示す. 表には葉状体の諸元, 設 置位置を示してある. A-1 は人工海草なし, その他の ケースは人工海草がある場合である. 人工海草ありの 4 ケースに用いた葉状体の素材は,すべてポリプロピレン である.ただし，A-2 の材質は他の 3 ケースのそれと は異なるものである.ここで，A-2 抢よび A-4 は, 著者ら（1990）が先に行った進行波による一連の水平固 定床模型実験において, その植生区域付近に堆積すると

表一1 人工海岸による堤体前面の洗掘対策実験ケース

\begin{tabular}{|c|c|c|c|c|c|c|}
\hline \multirow[b]{2}{*}{ ケース } & \multirow[b]{2}{*}{ 材 } & \multicolumn{4}{|c|}{ 葉状体の諸元 } & \multirow{2}{*}{$\begin{array}{l}\text { 堤体からの } \\
\text { 設置距離 } \\
(\text { (cm) }\end{array}$} \\
\hline & & $\begin{array}{l}\text { 長さ } \\
(\mathrm{cm})\end{array}$ & $\begin{array}{c}\text { 幅 } \\
(\mathrm{cm})\end{array}$ & $\begin{array}{l}\text { 厚さ } \\
(\mathrm{cm})\end{array}$ & 比重 & \\
\hline $\mathrm{A}-1$ & 人工海草なし & - & - & - & - & - \\
\hline$A-2$ & ポリプロピレン 21 & 20 & 1.6 & 0.45 & 0.45 & $0 \sim 100$ \\
\hline$A-3$ & ポリプロピレン & 20 & 1.0 & 0.15 & 0.65 & $100 \sim 200$ \\
\hline$A-4$ & $m$ & 10 & 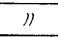 & $n$ & "1 & $0 \sim 100$ \\
\hline$A-5$ & $m$ & 5 & $m$ & $m$ & $m$ & $100 \sim 200$ \\
\hline
\end{tabular}

評価された人工海草の模型であり， $\mathrm{A}-3$ および $\mathrm{A}-5$ は植生区域の岸側に底質を移送させる効果があったもの である．実験では A-1 以外の 4 ケースについても砂 厚 $10 \mathrm{~cm}$ の水平移動床を初期地形としてある.なお, 人工海草の岸沖長は $L_{0} / 4$ である.

\section{(4) 実験結果および考察}

堤体から $300 \mathrm{~cm}$ の区間について, 図一 2 に全ケース の波高分布を示す. 堤体から $140 \mathrm{~cm}$ 付近の第 1 腹の波 高の最大は $\mathrm{A}-1$ では $20 \mathrm{~cm}, 250 \mathrm{~cm}$ 付近の第 2 腹の 波高の最大は $18 \mathrm{~cm}$ 強であるのに対し, 他のケースで はこれより小さい波高を示している. 特に A-2 は第 1 腹で $16.8 \mathrm{~cm}(83 \%)$ ，第 2 腹で $15.9 \mathrm{~cm}(86 \%)$ に低 減し, 他の 3 ケースでも第 1 腹では $18.1 \sim 18.5 \mathrm{~cm}(90$ 〜92\%)，第 2 腹では $17.0 \sim 17.5 \mathrm{~cm}(92 \sim 95 \%)$ であ る. 最も減衰する $\mathrm{A}-2$ の場合, 前資料（菅原・ 入江, 1990）で得られた進行波の波高は，人工海草がある場合 はそれがない場合の 90数\% 程度であったのに対し, 重 複波による第 1 腹の波高は, その 2 倍以上低減している ことになる。

図-3 に全ケース波作用 6 時間後の断面地形を示す. 図によれば堤体から $50 \mathrm{~cm}$ 付近の最大洗掘深は, 初期 地形面から A-1では $6.6 \mathrm{~cm}$ であるのに対し, 他のヶ ースでは最も洗掘される $\mathrm{A}-3$ が $4.32 \mathrm{~cm}$, 次いで $\mathrm{A}$ -5 の $4.27 \mathrm{~cm}, \mathrm{~A}-2$ の $4.12 \mathrm{~cm}, \mathrm{~A}-4$ の $3.22 \mathrm{~cm}$ の順でめり，A-3 の場合で $65 \%$ に A-4 では $49 \%$ に低減している.

人工海草なしに対するそれがある場合の地形変化の差

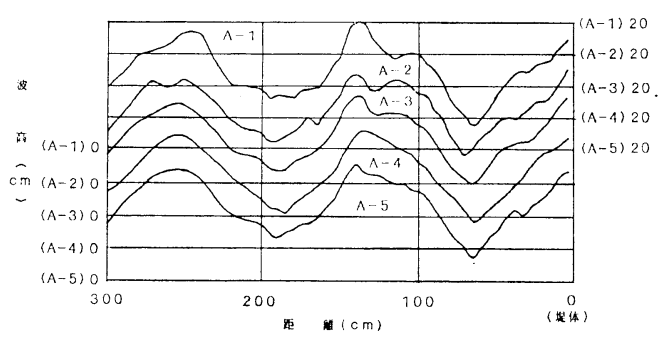

図-2 各ヶースの波高分布

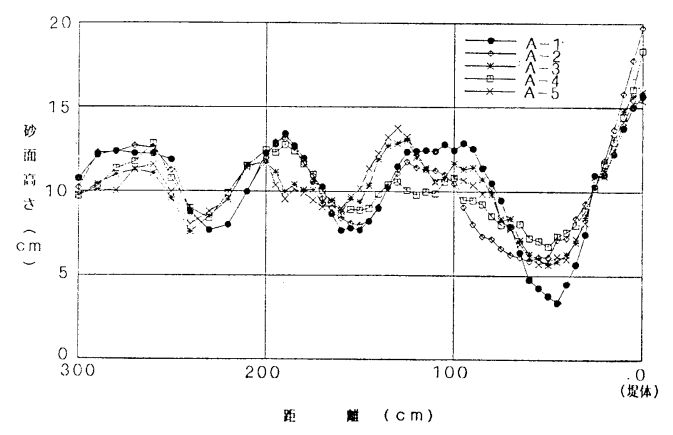

図-3 断面地形の比較（6 時間後） 
分を 図一 4 (a)，（b） に示す. 横軸は移動床部の堤体 から $300 \mathrm{~cm}$ までの水平距離, 縦軸は差分高さである. 縦軸のプラス側は, 人工海草がある場合はそれがない場 合の地形に対して，洗掘が低減するかまたは堆積するこ とを(以下, 堆積性という), マイナス側は堆積が低減 するか洗掘される（以下，洗掘性という）ことを表す.

まず図-4（a）は,ケース A-2，4のものである. $\mathrm{A}$-1に拈いて最大洗掘深を示した堤体より約 $50 \mathrm{~cm}$ の 位置をカバーする範囲に人工海草を設置した場合のもの である. 両ケースはほぼ似通った傾向を示し, 植生区域 内の中央部で顕著な堆積性を, 堤体直前にも堆積性を示 す. A-1 で堆積を示した $100 \mathrm{~cm}$ 付近は洗掘性であ り, $160 \mathrm{~cm}$ 付近の洗掘位置ではやや堆積性, $190 \mathrm{~cm}$ 付 近の堆積位置ではやや洗掘性を示す. したがって人工海 草は，それがない場合の洗掘位置が堆積に変わるほどの 効果は期待できないけれども洗掘深が浅くなり, その堆 積位置で快洗掘性を示し，平坦化の機能があることは明 らかである。

図一4（b） はケース $A-3 ， 5$ にいて示す. 人工 海草は A-1 に打ける最大洗掘域には置かず，堤体か ら $100 \mathrm{~cm}$ 離して設置してある. 図によれば $\mathrm{A}$-3 と 5 はほとんぞ同じ結果を示しており, 堤体より約 $50 \mathrm{~cm}$ 付近に強い堆積性を示し, さらに $150 \mathrm{~cm}$ の植生区域の 中央付近では, A-1 で洗掘域であるのに対して堆積性 が顕著であり，その前後の堆積位置では洗掘性を示して いる、すなわちこれらの人工海草は，底質を岸向きに移 送させるとともに植生区域内にも堆積させる機能を有し ている． A-3 と 5 は同じ材質で長さのみが異なるもの でこの図から長さの違いによる差異は見いだせない。

これらの結果から, 先に著者らが把握した人工海草の もつ堆積効果と岸向き漂砂効果の 2 つの機能が本実験で も明らかになった. な挔, 岸向き漂砂効果がある $\mathrm{A}$ 3,5 の場合の人工海草でも, 堤体直前すなわち洗掘位 置に設置すれば $\mathrm{A}-2 ， 4$ と同じように植生区域内の堆 積性が大きくなる地形変化を示すものと推察される.

(a) ケース $\mathrm{A}-2.4$ (谁啧勃果)

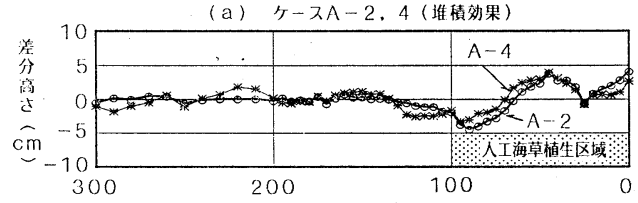

(b) ケースA - 3, 5. (岸向き漂砂奻果)

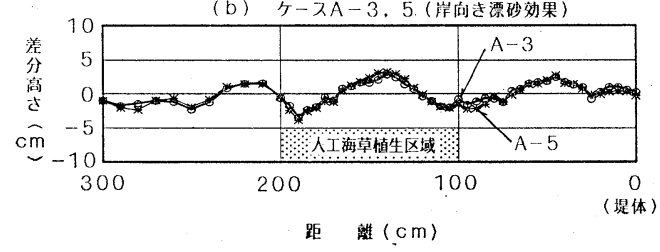

図一4人工海草なしに対する地形の差分

\section{3. 海岸侵食に対する人工海草模型実験}

\section{（1）実験の概要とケース}

実験に用いた水路は 2. と同じものである. 図一5 に 実験の概要を示す. 移動床は, 岸側端の消波工前面に底 質を投入し，まず岸側は高さ $50 \mathrm{~cm}$ の水平区間を岸沖 $50 \mathrm{~cm}$ とり，その先を $1 / 20$ の勾配として水路床面まで 全て移動床で成形した。実験波は $H=10 \mathrm{~cm}, T=1.6 \mathrm{~s}$ であり, 岩垣・野田（1961）による暴風海浜の性状をも つ波である. 水深は床面まで $40 \mathrm{~cm}$ である.

1 ケースに対する波の作用時間は人工海草がない場合 の実験ケースを行って，底質面がほぼ平衡状態となると 判断した延べ 7 時間とし, 人工海草模型の設置位置は, 砕波点揖よびバーの位置から判断して決定した. 移動床 の底質は 2. の実験で用いたものと同じである．測定項 目は断面地形，波高および砕波点の位置である.

断面地形の測定は, 水路幅約 $50 \mathrm{~cm}$ の中央とその両 側 $15 \mathrm{~cm}$ の岸沖 3 測線とし, $5 \mathrm{~cm}$ 間隔に行った。測定 の時間間隔初期地形と波作用 $0.5,1,3,5,7$ 時 間後とした。

波高は，容量式波高計を用いて 2 定点括よび波高分布 を求めるために測定した。砕波点は砕波頂の位置とし，

目視によって測定した.

本実験の目的とする海岸侵食の防止に対する人工海草 の設置位置は, (1)汀線付近, (2)砕波点の岸側, (3)砕波点 付近, (4)砕波点の沖側, (5)砕波点のさらに沖側と種々な 場所が考えられる．そこで現地に人工海草を設置する場 合の諸条件を勘案して考察すると，11は汀線付近の景観 を損ねるばかりでなく，例えば海水浴には不適である. (2)は人工海草の安定的設置が比較的容易であると考えら れ, 効果があれば設置可能な場所である. (3)海底面の 変動が大きく, 人工海草の長期的安定を保持するため に，技術的な不安が多い。(4)は砕波点付近で侵食された 底質がバーを形成する位置であるので，安定設置および 人工海草の機能が顕著に現れる場所と推察される. (5) 高波時に底質がこれより沖へ流出しなければ有効であ り, 水深もある程度確保できることから設置安定上有利 な場所である.このような観点から本実験は基本的に(4)

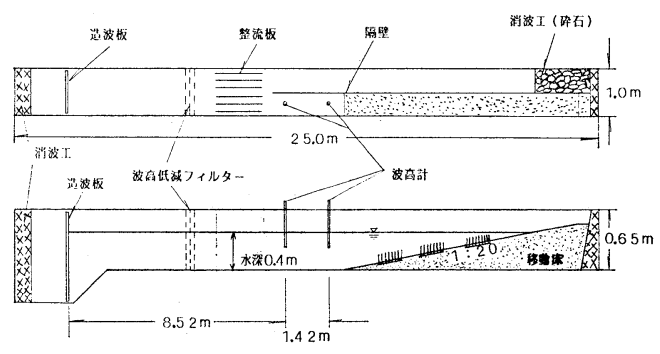

図一5人工海草に上る傾斜断面の侵食対策実験の概要 
表一2人工海草による傾斜断面の侵食対策実験ケース

\begin{tabular}{|c|c|c|c|c|c|c|c|c|c|c|}
\hline ケース & 材 & $\begin{array}{c}\text { 葉状体 } \\
\text { の辰さ } \\
(\mathrm{cm})\end{array}$ & $\begin{array}{c}\text { 砂面上 } \\
\text { の長さ } \\
(\mathrm{cm})\end{array}$ & $\begin{array}{c}\text { 幅 } \\
(\mathrm{cm})\end{array}$ & $\begin{array}{l}1 \text { 株の } \\
\text { 本数 } \\
(\text { 本 })\end{array}$ & $\begin{array}{l}\text { 厚さ } \\
(\mathrm{mm})\end{array}$ & 比重 & $\begin{array}{l}\text { 植生 } \\
\text { 間隔 } \\
(\mathrm{cm})\end{array}$ & $\begin{array}{c}\text { 植生区 } \\
\text { 域長 } \\
(\mathrm{cm})\end{array}$ & $\begin{array}{l}\text { 植生位置（初 } \\
\text { 期汀線からの } \\
\text { 距離） (cm) }\end{array}$ \\
\hline$B-1$ & 人工海草なし & - & - & - & - & - & - & - & - & $\longrightarrow$ \\
\hline$B-2$ & ポリプロピレン21 & 25 & 20 & 1.6 & 1 & 0.45 & 0.45 & 5 & 100 & $370 \sim 470$ \\
\hline$B-3$ & ポリプロピレン & 15 & 10 & 1.0 & 2 & $|0.15|$ & 0.65 & " & $n$ & $n \quad " 1$ \\
\hline$B-4$ & "1 & 10 & 5 & 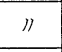 & 1 & 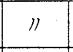 & 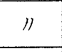 & "l & "1 & $n$ \\
\hline$B-5$ & "I & 15 & 10 & 11 & 11 & 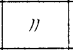 & "I & n & $n$ & $550 \sim 650$ \\
\hline$B-6$ & $" 1$ & $n$ & "I & 11 & 11 & "I & II & 11 & "1 & $170 \sim 270$ \\
\hline$B-7$ & "l & $n$ & "I & $n$ & $n$ & $n$ & "1 & $n$ & $n$ & $370 \sim 470$ \\
\hline$B-8$ & $" 1$ & 10 & 5 & $"$ & "I & $" 1$ & $n$ & "I & $n$ & $170 \sim 270$ \\
\hline
\end{tabular}

に設置することとし，他に(2)および(5について行った。

実験ケースを衰一 2 に示す。 ケース数は人工海草なし の1ケースを含め計 8 ケースである. 葉状体の材質およ び植生間隔，模型長は前述した 2. の実験で用いたるの と同じである.ただし，B-3 は B-7 の模型に対し， 1 株を 2 倍の本数にしてある. 人工海草模型の設置は, 人工海草なしの地形変化を観察し, 基盤が露出しないよ 与に初期地形に対して砂面から葉状体の取り付板上面 までのかぶりを $5 \mathrm{~cm}$ とって埋めてある.なお，人工海 草の岸沖長引 $L_{0} / 4$ である.

\section{(2) 実験結果と考察}

全ケースの変化地形を図一6に示す，図によればケー ス $\mathrm{B}-1$ の地形に対して, B- 2 は人工海草の植生区 域とそのすぐ岸沖に堆積し, 逆に B-3，4，7 はその 岸側に大きく堆積している. その他のケースはBー1 と そら異なっているよらには見えない。

砕波点付近に着目して図一7を示高。図には砕波点の 経時変化とバーの形状扣よび人工海草植生位置を示す。. バーは7 時間後の初期地形との差分でプラス部分のみ を，砕波点は矢印で示してある．短い矢印は 0.5 時間， これに横線 1 本が 1 時間， 2 本が 3 時間， 3 本が 5 時間 後で，長い矢印が 7 洔間後を表す、砕波点が移動しない 場合, 例えば B -8 では $1 ， 3 ， 5 ， 7$ 時間後の砕波 点が同位置で㐫ることを億味する.

図によれば，バーの位置，形状はそれぞれ特徵があ り, 砕波点の位置も巽なっている. B- 2 は人工海草植 生区域とその岸沖に幅広く堆積し，7時間後の砕波点は 全ケースのなかで最も沖側にある. B-3，4，7はど れも植生区域内の沖側が侵食されてより岸側に堆穦す る.なかでも植生密度の高い $\mathrm{B}-3$ が顕著であり, 7 時 間後の砕波点も最も岸側にある. B-5 は最も沖側に人 工海草を設置したケースであり, 植生区域内は全域が侵 食 (図一6 参照) されてその岸側にあたるバーが他のケ 一スよりやや沖側に位置するとともに堆積量も多い、研 波点の岸側に人工海草を設置した B-6，8 はバーの形

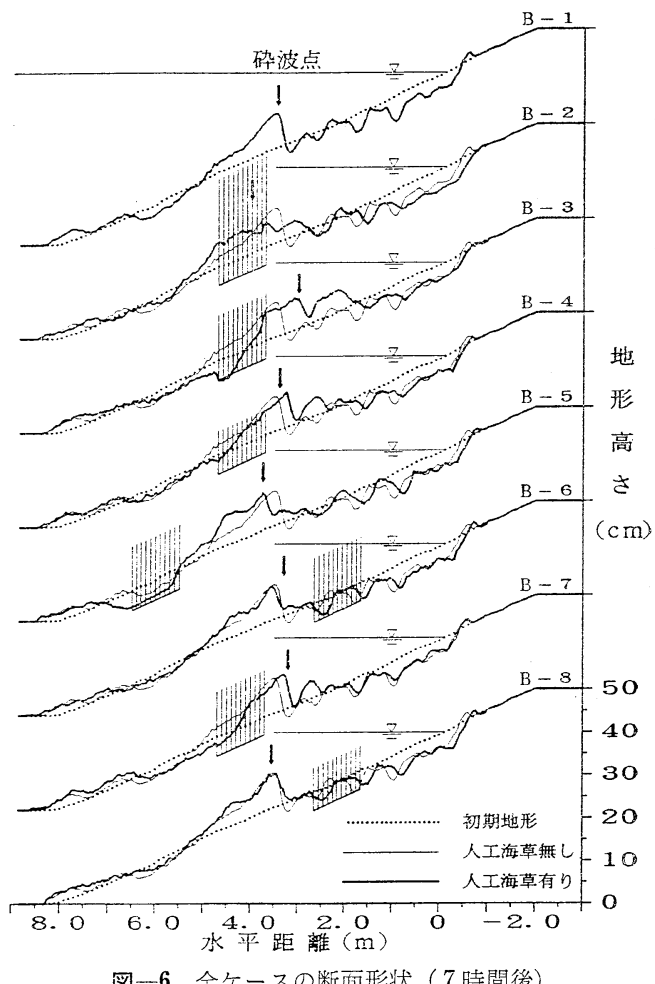

図一6 全ケースの断面形状 ( 7 時間後)

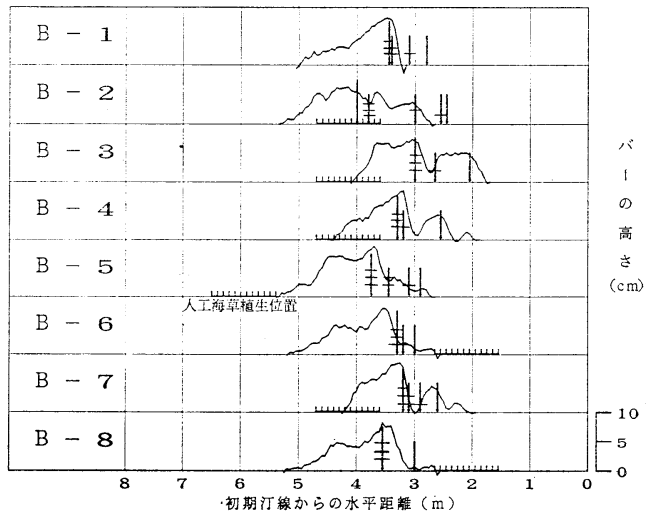

図一7 バーの形成と砕波点の経時変化 
状および厒波点の位置とも B-1 とあまり変わっていな い.な抢，砕波点は全ケースとも時間の経過とともに沖 側に移動している.

人工海草はバー付近に設置すると底質移動の制御効果 が顕著であり, 砕波点のさらに沖側に設置した場合も バーを発達させる. この効果は植生密度が高い方が大き くなる結果が得られた。

断面全体の底質 の 岸沖累積量の比較を 図一8 (a), （b）に示す. 横軸は水平距離, 縦軸は陸上部を基点と した累積量を示す. 図中の数字はケース番号である.

(a) 困は人工海草なし（B-1）においてバーが形成 される位置に人工海草を設置した 4 ケース，(b) 眓は それ以外の 3 ケースで，それぞれ B-1 とともに示す.

(a) 四からわかるように B-3, 7, 4 の順で, 人工海草 の岸側に顕著なプラスの累積量を示すとともにそのピー クも同じ順序でより岸側にある. 一方, 図一7で人工海 草植生区域内和よびその岸沖に広範かつ顕著な堆積を示 した B一2 は砕波点の岸側から汀線にかけてマイナスの 累積量が多く, プラスの累積量は $\mathrm{B}-1$ より僅かに多い 程度である。一方，（b）図によれば，B-5 が他のヶ ースと大きく異なっている.このケースは B-1におけ る砕波点のさらに沖㑡に人工海草を設置した場合で，そ の植生位置のすぐ岸側に顕著なプラスの累積量を示す. 研波帯内は他の 3 ケースとあまり違わない.人工海草を
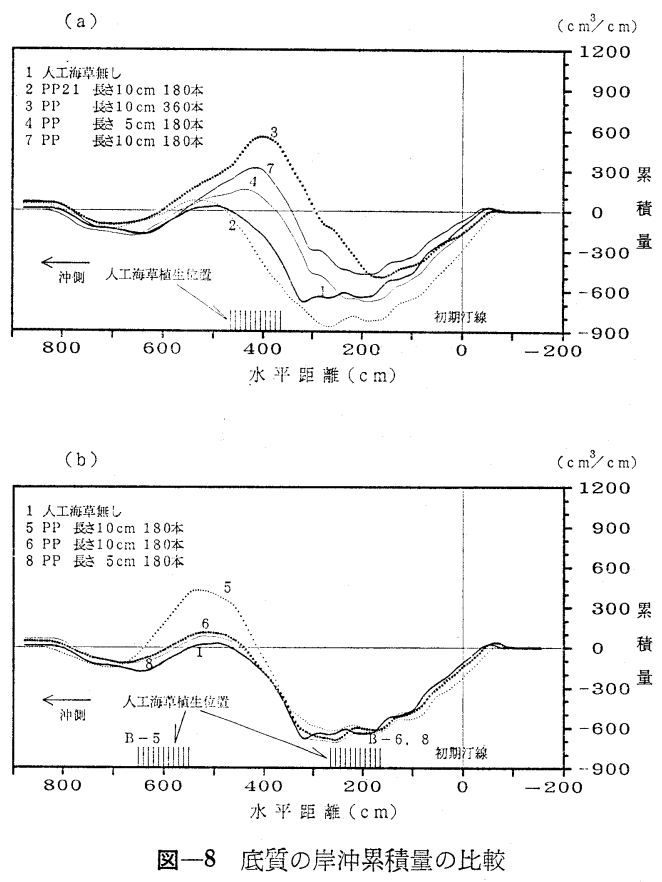

B-1 の砕波点の岸側に設置した B-6および 8 は，プ ラスの堆積量がわずかに多くなるほかは B-1 とほぼ同 じ累積変化を示す。

したがって，海岸侵食の防止には，高波時に柔軟な人 工海草をバー付近からその沖側に置けば，植生区域の岸 側により多くの堆積が期待できる. 長さの違いは B-4 と 7 の差であり, 植生密度の違いは $\mathrm{B}-7$ と 3 の差であ る.なお，人工海草がある場合の汀線は総じて後退する 傾向がある.

\section{4. おわりに}

本研究は, 現実に問題となっている波による海中構造 物前面の海底洗掘掞よび海岸侵食に対して人工海草の機 能を模型実験により検討したものである。その結果以下 と示す結論が得られた。

(1) 堤体前面の洗掘に対して, 洗掘域に堆積効果のあ る人工海草を岸沖に $L_{0} / 4$ 程度設置した場合, 最大洗掘 が深 40〜50\% 程度低減し, またその沖側の堆積域に岸 向き漂砂效果のある人工海草を設置すればそれが $35 \%$ 程度低減するとともにその場の堆積も低隇する。

(2) 海岸侵食に対しては, 人工海草を砕波点の寸ぐ沖 側和よびさらにその沖側に岸沖 $L_{0} / 4$ 程度設置すれば底 質は植生区域から岸側に著しく堆積する。植生密度は高 ものが効果がある、ただし，人工海草があると汀線が後 退する傾向がある。

今後は現地用人工海草装置としての葉状体の諸元, 基 盤, 葉状体の取り付け方法, アンカーリング, 設置方法 等の具体的な検討を行い，考察する所存である.

実験材料は日本化学繊維協会拈よび関係各社から, 伸 紀（株）からは材料と共に最近の情報の提供を受けた。

九州大学工学部入江 功教授, 当所水工部加藤一正漂 砂研究室長には全般にわたる適切なご助言を，水工部栗 山善昭主任研究官には助力をいただいた、実験には(株) エコー調査役三沢邦弘氏が当たられた。実験の一部およ び作図のほとんどは海象調查研究室平野隆幸研究員が行 った．これらの方々に感謝の意を表します。

\section{参考文 献}

入江 功・灘岡和夫·近藤隆道・寺崎賢次 (1984)：重複波に 上る防波堤前面での二次元的海底洗掘, 港湾技術研究所報 告, 第 23 巻, 第 1 号, pp. $3-52$.

岩坦雄一・野田英明 (1961)：海岸変形の実験における縮尺効 果の研究, 第 8 回海岸工学講演会講演集, pp. 139-143.

菅原一晃・入江 功 (1990): 人工海草迈底質移動の制御効 果につ々て, 海岸工学論文集, 第 37 巻, pp. 434-438.

营原一晃・入江 功 (1990)：人工海草による底質移動の制御 効果汇関する模型実験，港湾技研資料，No. 692，48 p. 